\title{
PERBEDAAN EFEKTIVITAS EKSTRAK IKAN GABUS DAN DAUN BINAHONG TERHADAP LAMA PENYEMBUHAN LUKA OPERASI SECTIO CAESAREA PADA IBU NIFAS
}

\author{
Intan Nugraheni, Ari Kurniarum \\ Kementerian Kesehatan Politeknik Kesehatan Surakarta Jurusan Kebidanan
}

\begin{abstract}
Mother Parturition, Sectio Caesarea, Wound Healing. To identify differences in the effectiveness of extracts of catfish and leaves binahong towards healing old wounds sectio caesarea operation on postpartum mothers. There is a difference in the effectiveness of extracts of catfish and leaves binahong towards healing old wounds sectio caesarea operation on postpartum mothers. The study design was Quasi Experimental research design with pretest - posttest nonequivalent control group. The sampling technique was accidental sampling technique. Number of samples 60 puerperal women with puerperal women inclusion criteria primi and multiparous, type transverse incision, wound care treatment and the same. Statistical analysis using the Wilcoxon test with significant value in the study was $p<0.05$. The average length of the wound healing process operation sectio caesarea in postpartum mothers who consume fish extract the cork is 8 days, binahong leaf extract is 12 days whereas the control group without treatment was 16 days. There are differences in the effectiveness of extracts of catfish and leaves binahong towards healing old wounds sectio caesarea operation in puerperal women with $p$ value 0.013. There are differences in the effectiveness of extracts of catfish and leaves binahong towards healing old wounds sectio caesarea operation at BPM puerperal women in the District of Tulung with $p=$ $0.013(p<0.05)$.
\end{abstract}

\section{Keywords: Mother Parturition, Sectio Caesarea, Wound Healing}

Abstrak : Ibu Nifas, Sectio Caesarea, Lama Penyembuhan Luka. Tujuan penelitian ini adalah untuk mengetahui perbedaan efektivitas ekstrak ikan gabus dan daun binahong terhadap lama penyembuhan luka operasi sectio caesarea pada ibu nifas. Desain penelitian Quasi Eksperimen dengan pre test - post test nonequivalent control group. Teknik pengambilan sampel adalah teknik accidental sampling. Jumlah sampel 60 ibu nifas dengan kriteria inklusi ibu nifas primi dan multipara, jenis insisi transversal, mendapatkan pengobatan dan perawatan luka yang sama. Analisis statistik menggunakan uji Wilcoxon dengan nilai signifikan dalam penelitian adalah $\mathrm{p}<0,05$. Rata-rata lama proses penyembuhan luka operasi sectio caesarea pada ibu nifas yang mengkonsumsi ekstrak ikan gabus adalah 8 hari, ekstrak daun binahong adalah 12 hari sedangkan pada kelompok kontrol tanpa perlakuan adalah 16 hari. Ada perbedaan efektivitas ekstrak ikan gabus dan daun binahong terhadap lama penyembuhan luka operasi sectio caesarea pada ibu nifas dengan nilai $\mathrm{p}=0,013(\mathrm{p}<0,05)$. Ada perbedaan efektivitas ekstrak ikan gabus dan daun binahong terhadap lama penyembuhan luka operasi sectio caesarea pada ibu nifas di BPM wilayah Kecamatan Tulung dengan nilai $\mathrm{p}=0,013(\mathrm{p}<0,05)$. 
Kata kunci : Ibu Nifas, Sectio Caesarea, Lama Penyembuhan Luka

\section{PENDAHULUAN}

Sectio Caesarea adalah suatu persalinan buatan dimana janin dilahirkan melalui suatu insisi pada dinding perut dan dinding rahim dengan sayatan rahim dalam keadaan utuh serta berat janin diatas 500 gram (Dewi, 2007).

Infeksi perlukaan pada dinding rahim ini bisa terjadi karena ibu tidak memperhatikan personal hygiene yang baik. Ibu tidak mengerti cara merawat luka pada dinding perut begitu pula alatalat dan pakaian serta kain yang berhubungan dengan alat kandungan kurang steril. (Guyton, 2008).

Periode awal penyembuhan luka pasca operasi secsio caesaria adalah 7-14 hari. Fenomena yang ada di masyarakat sudah mengetahui bahwa penyembuhan luka dibutuhkan makanan yang banyak mengandung protein. Salah satu sumber makanan yang kaya akan protein adalah ikan gabus. Ikan kutuk mengandung protein yang lebih tinggi dibanding jenis ikan yang lain. Protein diperlukan untuk tubuh dan berfungsi untuk meningkatkan daya tahan tubuh, mempercepat penyembuhan luka pasca operasi dan membantu proses metabolisme tubuh (Mochtar, 2000).

Ikan kutuk merupakan salah satu jenis ikan yang banyak digunakan oleh masyarakat untuk penyembuhan luka terutama luka pasca operasi, luka bakar dan setelah persalinan karena kandungan utama dalam ikan kutuk adalah protein atau albumin yang cukup tinggi dan juga albumin merupakan protein terbanyak dalam plasma sekitar $60 \%$ dari total plasma dengan nilai normal 3,3-5,5 g/dl albumin juga didapatkan pada ruang ekstrasel $40 \%$ terdapat pada plasma dan 60\% ekstrasel. (Fadli, 2010).

Daun binahong sering digunakan masyarakat untuk pemulihan luka dalam maupun luar. Pemanfaatan daun binahong ini dengan cara direbus atau sebagai lalapan atau sebagai campuran saat memasak. Protein yang ada di dalam binahong obat adalah berat molekul yang besar dan merupakan antigen yang bisa memacu terjadinya pembentukan antibodi. (Arisandi, 2008).

Berdasarkan fenomena-fenomena tersebut maka penulis merasa tertarik untuk melakukan penelitian tentang "Perbedaan Efektivitas Ekstrak Ikan Gabus dan Daun Binahong terhadap Lama Penyembuhan Luka Operasi Sectio Caesarea pada Ibu Nifas".

\section{METODE PENELITIAN}

Desain penelitian pre-experimental design dengan pendekatan static group comparison. Rancangan penelitian dilakukan dengan mengelompokkan anggota-anggota dalam kelompok kontrol dan kelompok eksperimen.

Pada kelompok eksperimen dilakukan intervensi berupa pemberian esktrak ikan gabus dan daun binahong selama 14 hari dengan dosis 3 kali sehari 0,25 gram diminum 1 jam sebelum makan kemudian dilakukan observasi selama 14 hari pada kedua kelompok tersebut.

Pelaksanaan penelitian dilakukan pada bulan Januari - Juni 2015 di Bidan Praktik Mandiri (BPM) wilayah kecamatan Tulung Klaten.

Populasinya adalah seluruh ibu yang bersalin SC di BPM wilayah Kecamatan Tulung pada tahun 2015. Sedangkan tehnik pengambilan sampel 
dengan accidental sampling yaitu sampelnya adalah ibu nifas primipara /multipara yang bersalin SC di BPM wilayah Kecamatan Tulung dengan kriteria inklusi yaitu mendapatkan jahitan tranversal $\pm 10 \mathrm{~cm}$, perawatan dan pengobatan yang sama.

Jumlah sampel dalam penelitian ini adalah 60 ibu nifas post SC yang terdiri dari 40 ibu nifas post SC sebagai kelompok eksperimen, dan 20 ibu nifas post SC sebagai keompok kontrol.

Analisis statistik yang digunakan dalam penelitian ini terdiri atas: (1) Analisis univariabel, dilakukan untuk menggambarkan data demografi atau karakteristik ibu nifas dan rerata sebelum dan sesudah diberi perlakuan. Analisis ini disajikan dalam bentuk distribusi frekuensi. (2) Analisis bivariabel, digunakan untuk mengetahui Perbedaan Efektivitas Ekstrak Ikan Gabus dan Daun Binahong terhadap Lama Penyembuhan Luka Operasi Sectio Caesarea pada Ibu Nifas. Uji statistik yang digunakan dalam penelitian ini adalah uji wilcoxon.

\section{HASIL PENELITIAN}

A. Hasil Penelitian

Analisis Univariat

Tabel 1

Rerata lama penyembuhan luka SC dengan ikan gabus

\begin{tabular}{lcccc}
\hline \multirow{2}{*}{ Ekstrak } & \multicolumn{4}{c}{ Lama Penyembuhan } \\
\cline { 2 - 5 } & Min & Maks & Mean & SD \\
\hline Gabus & 6 & 15 & 0,80 & 0,410 \\
Kontrol & 14 & 23 & 0,30 & 0,470 \\
\hline
\end{tabular}

Tabel 2

Rerata lama penyembuhan luka SC dengan daun binahong

\begin{tabular}{lcccc}
\hline \multirow{2}{*}{ Ekstrak } & \multicolumn{4}{c}{ Lama penyembuhan } \\
\cline { 2 - 5 } & Min & Maks & Mean & SD \\
\hline Binahong & 8 & 18 & 0,35 & 0,109 \\
Kontrol & 14 & 23 & 0,35 & 0,109 \\
\hline
\end{tabular}

Analisis Bivariat

Tabel 3

Perbedaan efektivitas ekstrak ikan gabus dan daun binahong terhadap lama penyembuhan luka SC

\begin{tabular}{lccc}
\hline Ekstrak & $\mathrm{Z}$ & Mean & $\mathrm{p}$ \\
\hline $\begin{array}{l}\text { Ikan Gabus } \\
\text { Binahong }\end{array}$ & 2.496 & 39,50 & 0,013
\end{tabular}

Berdasarkan tabel 3 diatas dapat dilihat bahwa lama proses penyembuhan luka operasi SC pada kelompok ikan gabus mínimum 6 hari dan maksimum 15 hari, sedangkan pada kelompok kontrol mínimum 14 hari dan maksimum 23 hari. Rata-rata lama penyembuhan pada kelompok ekstrak ikan gabus 0,80 \pm 0,410. Sedangkan pada pada kelompok tidak diberi ekstrak ikan gabus rata-rata lama penyembuhan $0,30 \pm 0,470$.

Berdasarkan tabel 5.5 dapat diketahui bahwa lama penyembuhan pada kelompok daun binahong paling sedikit 8 hari, dan paling lama 18 hari, rata-rata lama penyembuhan $0,35 \pm 0,109$. Sedangkan pada lama penyembuhan pada kelompok tanpa diberi paling sedikit 14 hari dan paling lama 23 hari, rata-rata 0,35 $\pm 0,109$.

Hasil analisa menggunakan uji Wilcoxon didapatkan nilai $\mathrm{Z}=2,496$, Mean $=39,50$ dengan nilai $\mathrm{p}=0,013$ $(\mathrm{p}<0,05)$, sehingga dapat diambil kesimpulan bahwa ada perbedaan efektivitas ekstrak ikan gabus dan daun binahong terhadap lama penyembuhan luka operasi SC pada ibu nifas di BPM wilayah Kecamatan Tulung Klaten.

\section{PEMBAHASAN}

Hasil penelitian menunjukkan bahwa sebagian besar responden dengan umur 20-35 tahun sebanyak 62 orang $(77,5 \%)$. Data ini menunjukkan bahwa umur responden termasuk dalam umur 
produktif karena terletak antara 20-35 tahun. Hasil ini sesuai dengan teori Wiknjosastro (2010) umur ibu yang produktif untuk hamil, bersalin dan nifas serta menyusui adalah umur 20-35 tahun. Hasil penelitian sesuai dengan penelitian Nelly (2009), tentang Pengaruh pemberian ekstrak ikan gabus pada ibu nifas terhadap proses penyembuhan luka perineum di Tulip II RS dr. Soepranoen Malang bahwa umur ibu nifas sebagian besar adalah 2035 tahun.

Pemberian ikan gabus pada kelompok perlakuan dimaksudkan untuk mempercepat penyembuhan luka post SC. Sebab ikan gabus merupakan salah satu jenis ikan yang kandungan utamanya adalah protein atau albuminnya yang cukup tinggi. Sedangkan salah satu faktor proses percepatan penyembuhan luka jahitan post SC yaitu membutuhkan protein tinggi yang terdapat pada ikan gabus. Kandungan protein ikan gabus juga lebih tinggi daripada bahan pangan yang selama ini dikenal sebagai sumber protein seperti telur, daging ayam, maupun daging sapi. Karena kandungan inilah, ikan gabus memiliki manfaat atau kegunaan yang sangat tinggi untuk mempercepat penyembuhan luka jahitan post SC. Konsumsi ikan gabus salah satunya dilatarbelakangi oleh umur responden. Umur yang cukup matang menyebabkan responden pada kelompok perlakuan yang mendapatkan ikan gabus mampu menyadari pentingnya mengkonsumsi ikan gabus sebagai alternatif pengobatan yang mempercepat penyembuhan luka jahitan yang dialaminya. Hal ini mempengaruhi pula ketaatannya dalam mengkonsumsi ikan gabus selama penelitian. Hal ini sesuai dengan penelitian yang dilakukan oleh Prof. DR. Dr. Nurpudji A. Taslim dari Universitas
Hasanuddin, Makasar yang menunjukkan kadar albumin pasien di RS Wahidin Sudiro Husodo Makasar, Sul-Sel, meningkat tajam setelah beberapa kali mengkonsumsi ikan gabus. Penelitian serupa juga pernah dilakukan pada bagian bedah RS Umum Dr. Saiful Anwar Malang. Hasil uji coba tersebut menunjukkan albumin dari kadar yang rendah $(1,8 \mathrm{~g} / \mathrm{dl})$ menjadi normal. Penelitian yang dilakukan di Universitas Hasanudin juga menunjukkan pemberian ekstrak ikan gabus selama 10-14 hari dapat meningkatkan kadar albumin darah 0,6-0,8 g/dl. Albumin merupakan protein yang paling banyak terkandung dalam plasma ikan gabus, sekitar $60 \%$ dari total plasma, atau 3,5 sampai 5,5 g/dl (www.sariikankutuk.com/2007).

Berdasarkan hasil penelitian bahwa pada kelompok ekstrak ikan gabus didapatkan sebanyak 14 orang (70\%) luka post SC sudah kering dan 4 orang (20\%) masih basah. Pengetahuan ibu tentang perawatan pasca operasi SC sangat menentukan lama penyembuhan luka jahitan. Apabila pengetahuan ibu kurang terlebih masalah makan-makanan yang dikonsumsi maka penyembuhan luka pun akan berlangsung lama. Pengetahuan salah satunya dipengaruhi oleh tingkat pendidikan. Tingkat pendidikan sangat berpengaruh terhadap perubahan sikap dan perilaku hidup sehat. Tingkat pendidikan yang lebih tinggi akan memudahkan seseorang atau masyarakat untuk menyerap informasi dan mengimplementasikannya dalam perilaku dan gaya hidup sehari-hari, khususnya dalam hal kesehatan dan gizi. Tingkat pendidikan, khususnya tingkat pendidikan wanita mempengaruhi derajat kesehatan (Atmarita dan Fallah, 2004). Pengaruh dari kondisi sosial ekonomi ibu dengan 
lama penyembuhan luka adalah keadaan fisik dan mental ibu dalam melakukan aktivitas sehari-hari pasca operasi. Jika ibu memiliki tingkat sosial ekonomi yang rendah, bisa jadi penyembuhan luka jahitan berlangsung lama karena timbulnya rasa malas dalam merawat diri (Smeltzer, 2002: 493). Tingkat pendapatan yang nyata dari keluarga menentukan jumlah dan kualitas makanan yang diperoleh. Pada tingkat pendapatan yang rendah sumber energi terutama diperoleh dari padi-padian, umbi-umbian dan sayur-sayuran. Hasil penelitian pada kelompok yang menggunakan daun binahong sebagian besar masih basah sebanyak 13 orang $(65 \%)$ dan yang kering hanya 7 orang $(35 \%)$. Hal tersebut berbeda secara signifikan dengan kelompok yang diberi perlakuan dengan daun binahong. Kelompok yang tidak diberi perlakuan atau tidak diberi ekstrak daun binahong dan ekstrak ikan gabus sebanyak 28 orang $(70 \%)$ luka post operasi masih basah. Sedangkan 12 orang (30\%) luka post operasi sudah sembuh atau kering. Data tersebut menunjukkan bahwa kelompok yang tidak menggunakan ekstrak ikan gabus maupun daun binahong sebagian besar masih belum sembuh, karena tidak ada inflamasi sehingga luka masih basah. Namun dari hasil penelitian didapatkan responden dengan luka kering, hal ini dikarenakan faktor yang mempengaruhi lama penyembuhan adalah status nutrisi, merokok, penambahan usia, obesitas, diabetes mellitus, kortikosteroid, obatobatan, gangguan oksigenasi, infeksi dan stress luka (Anggraini, 2010).

Berdasarkan hasil penelitian didapatkan bahwa terdapat perbedaan lama proses penyembuhan luka pada kelompok ekstrak ikan gabus dengan kelompok yang tidak diberi perlakuan dengan nilai $\mathrm{p}=0,004(\mathrm{p}<0,05)$. Hasil ini dikarenakan dengan ekstrak ikan kutuk dapat menambah kandungan albumin dan meningkatkan protein sehingga luka lebih cepat sembuh dan pulih. Luka dikatakan sembuh jika terjadi kontinuitas lapisan kulit dan kekuatan jaringan kulit mampu atau tidak mengganggu untuk melakukan aktivitas yang normal. Meskipun proses penyembuhan luka sama bagi setiap penderita, namun hasil yang dicapai sangat tergantung dari kondisi biologik masing-masing individu, lokasi serta luasnya luka. Penderita muda dan sehat akan mencapai proses yang cepat dibandingkan dengan kurang gizi, disertai dengan penyakit sistemik (diabetes melitus).

Penelitian ini menunjukkan bahwa ada perbedaan efektivitas ekstrak ikan gabus dan daun binahong terhadap lama penyembuhan luka operasi sectio caesarea pada ibu nifas dengan nilai $\mathrm{p}=0,013$ $(\mathrm{p}<0,05)$. Hasil penelitian menunjukkan ada perbedaan lebih cepat ikan gabus sebanyak 39,500 dibandingkan dengan daun binahong. Hal ini dikarenakan ikan gabus merupakan salah satu jenis ikan yang banyak digunakan oleh masyarakat untuk penyembuhan luka terutama luka pasca operasi, luka bakar dan setelah persalinan karena kandungan utama dalam ikan gabus adalah albumin yang cukup tinggi yang merupakan protein terbanyak dalam plasma sekitar $60 \%$ dari total plasma dengan nilai normal 3,3-5,5 g/dl. Albumin juga didapatkan pada ruang ekstrasel $40 \%$ terdapat pada plasma dan $60 \%$ ekstrasel. Salah satu faktor proses percepatan penyembuhan luka jahitan yaitu membutuhkan protein tinggi yang terdapat pada ikan gabus. Setelah diberikan konsumsi ikan gabus diharapkan 
dapat mempercepat penyembuhan luka sebelum hari ke-10 (Fadli, 2010).

Sedangkan daun binahong sering digunakan masyarakat untuk pemulihan luka dalam maupun luar. Pemanfaatan daun binahong ini dengan cara direbus atau sebagai lalapan atau sebagai campuran saat memasak. Protein yang ada di dalam binahong obat adalah berat molekul yang besar dan merupakan antigen yang bisa memacu terjadinya pembentukan antibodi. Kemudian antibodi ini akan mengakitifkan ke kembali komplemen. Protein ini juga bisa membantu untuk menstimulasi produksi nitrit oksida. Nitrit oksida yang bisa membantu untuk meningkatkan aliran darah dan untuk melancarkan proses sirkulasi darah yang akan membawa nutrisi ke dalam tiap jaringan sel. Dan selain itu juga, nitrit oksida bisa merangsang tubuh untuk membantu memproduksi hormon pertumbuhan yang mempunyai manfaat untuk menstimulasi pertumbuhan dan juga reproduksi sel yang mengalami kerusakan sehingga luka akan cepat sembuh (Arisandi, 2008).

\section{KESIMPULAN DAN SARAN}

Kesimpulan yang dapat ditarik dari hasil penelitian ini adalah. Rata-rata lama proses penyembuhan luka operasi sectio caesarea pada ibu nifas yang mengkonsumsi ekstrak ikan gabus di BPM wilayah Kecamatan Tulung adalah 8 hari. Rata-rata lama proses penyembuhan luka operasi sectio caesarea pada ibu nifas yang mengkonsumsi ekstrak daun binahong di BPM wilayah Kecamatan Tulung yaitu 12 hari. Rata-rata lama proses penyembuhan luka operasi sectio caesarea pada ibu nifas pada kelompok kontrol di BPM wilayah Kecamatan Tulung yaitu 16 hari. Ada perbedaan efektivitas ekstrak ikan gabus dan daun binahong terhadap lama penyembuhan luka operasi sectio caesarea pada ibu nifas di BPM wilayah Kecamatan Tulung dengan nilai $\mathrm{p}=0,013(\mathrm{p}<0,05)$.

Hasil penelitian ini dapat digunakan sebagai masukan untuk menambah wawasan tentang khususnya tentang ikan gabus dan daun binahong terhadap lama penyembuhan luka operasi secsio caesarea pada ibu nifas.

\section{DAFTAR RUJUKAN}

Anggraini, 2010. Asuhan Kebidanan Masa Nifas. Pustaka Rihama. Yogyakarta.

Arisandi dan Andriani. 2008. Khasiat Tanaman Obat. Pustaka Buku Murah. Jakarta.

Dewi, Y. dan H.Fauzi. 2007. Operasi Caesar Pengantar Dari A sampai Z. Jakarta : Edsa Mahkota.

Fadli, Oktober 2010. Bagusnya Ikan Gabus.Warta Pasarikan Edisi No.86, hal. 4-5

Guyton. 2008. Buku Ajar Fisiologi Kedokteran.Edisi 11. Jakarta : Hal 896

Mochtar, Rustam. 2000. Sinopsis Obstetri. EGC. Jakarta.

Suprayitno, E. 2003. Albumin Ikan Gabus Sebagai Makanan Fungsional Mengatasi Permasalahan Gizi Masa Depan. Fakultas Perikanan Universitas Brawijaya Malang.

Widianto Gianto dan Rostiawati Yustina. (1998). Persalinan Dengan Bedah Caesar. Jakarta: Arcan 